\title{
Turbulence model validation for fire simulation by CFD and experimental investigation of a hot jet in crossflow
}

\section{Doctoral Thesis}

Author(s):

Rusch, Daniel

Publication date:

2007

Permanent link:

https://doi.org/10.3929/ethz-a-005319599

Rights / license:

$\underline{\text { In Copyright - Non-Commercial Use Permitted }}$ 
Diss. ETH No. 16966

\title{
Turbulence Model Validation for Fire Simulation by CFD and Experimental Investigation of a Hot Jet in Crossflow
}

\author{
A dissertation submitted to the \\ Swiss Federal Institute of Technology, Zurich \\ for the degree of \\ Doctor of ScIEnces
}
Presented by
DANiel Bernhard Rusch
Dipl. Masch.-Ing. ETH, Zurich
born October 14, 1977
citizen of
Appenzell, AI

Accepted on the recommendation of

Prof. Dr. T. Rösgen, examiner

Prof. Dr. E. Lang, co-examiner

Dr. A. Moser, co-examiner 


\begin{abstract}
With the increase in computational power and the advances in Computational Fluid Dynamics (CFD) in recent years, it became possible to calculate temperature distributions, smoke spread, and velocity fields for fire scenarios in complex geometries. The CFD technique is becoming a standard tool to provide evidence and certification of fire safety for buildings and tunnels. Both structural considerations as well as the available time for evacuation can be investigated. In addition, emergency ventilation schemes and fire fighting strategies can be tested without the requirement for expensive experiments.

This thesis investigates the influence of the turbulence model choice on the solution of fire scenario simulations. Therefore a generic test case, a hot jet in a confined crossflow configuration, is considered. This configuration is similar to a fire in a tunnel or a long corridor with natural or forced ventilation. Having no chemical reactions, no combustion model has to be applied, and the influence of the turbulence model can be examined separately.

A new experimental setup has been designed and built to obtain experimental data. It consists of a $10 \mathrm{~m}$ long tunnel with a cross-section of $0.8 \mathrm{~m} \times 0.8 \mathrm{~m}$ which is longitudinally ventilated. The heat source has a diameter of $0.2 \mathrm{~m}$ and consists of a blower and an electric heater which delivers hot air at about $500^{\circ} \mathrm{C}$. The modular and tiltable tunnel has insulated walls and an insulated ceiling. The floor is made of glass which allows for optical access. A two-component Laser Doppler Anemometry system, LDA, is employed for velocity measurements, and thermocouples are used to acquire temperature profiles. Besides the validation measurements in the downstream region of the jet, the inflow boundary conditions of the computational domain are also obtained from measurements. Ordinary cooking salt crystals are successfully employed as seeding material for both the hot and the cold flow. Standard ultrasonic atomizers are used for the seeding particle production at high volumeflow-rate. The seeding salt crystal size distribution has been measured for various salt concentrations and an analytical model is discussed. It shows that the seeding size distribution can be controlled through the salt concentration and tuned for a given experimental requirement.
\end{abstract}

Two sets of numerical simulations have been performed: Steady computations on a grid with non-resolved walls and transient simulations on a grid with resolved walls. The steady simulations all fail in predicting the flow field accurately and the results depend strongly on the choice of the turbulence model. The ceiling temperatures are higher compared to the transient simulations due to the missing entrainment of the vortical structures near the jet. The transient simulations resolve the vortical structures in the jet vicinity. The transient Shear-Stress Transport (SST) model only resolves the dominant modes of the vortical structures leading to a slightly improved result compared to the steady one. The Detached Eddy Simulation (DES) shows more resolved structures but the applied grid is not fine enough and the model switches back into the SST mode in a large portion of the domain. On the same grid, the new Scale-Adaptive Simulation (SAS) shows very good results for both the velocity and the temperature resolving vortical structures down to a small scale. Only close to the jet discrepancies are still significant. It is the only model which can accurately capture the shedding frequency of the wake vortices and reproduce the backflow at the ceiling close to the hot jet source. 


\section{Kurzfassung}

Durch die rasante Zunahme der verfügbaren Rechenleistungen und dank den erzielten Fortschritten in den numerischen Berechnungsverfahren und der physikalischen Modellierung ist es heutzutage möglich, Temperatur-, Rauch- und Geschwindigkeitsverteilungen für Feuerszenarien in komplexen Geometrien zu berechnen. Die numerische Strömungssimulation (CFD) wird mehr und mehr zum Standardwerkzeug, um die Brandsicherheit von Gebäuden und Tunnels nachzuweisen. Nebst der verfügbaren Evakuierungszeit und der thermischen Belastung des Gebäudes können sowohl die Wirksamkeit von Lüftungsanlagen als auch Brandbekämpfungsstrategien untersucht werden, ohne dass teure Experimente durchgeführt werden müssen.

Diese Arbeit untersucht, welchen Einfluss die Wahl des Turbulenzmodells auf die Lösung der CFD Berechnung eines Brandszenarios hat. Dazu wird der generische Testfall eines Heissluftstrahls in einer räumlich eingeschränkten Queranströmung untersucht. Diese Konfiguration gleicht dem Szenario eines Brandes in einem Korridor oder in einem Tunnel mit erzwungener oder natürlicher Längslüftung. In dieser Konfiguration treten keine zu modellierenden Verbrennungsprozesse auf, was eine gezielte Untersuchung des Turbulenzmodelleinflusses erlaubt.

Um die für die Validierung notwendigen Messdaten zu erhalten, wurde eigens eine neue Anlage entwickelt und aufgebaut. Sie besteht aus einem mehr als $10 \mathrm{~m}$ langen, längsgelüfteten Kanal, der einen Querschnitt von $0.8 \mathrm{~m}$ mal $0.8 \mathrm{~m}$ aufweist. Eine Wärmequelle, bestehend aus einem Gebläse und einem elektrischen Heizer, liefert $500^{\circ} \mathrm{C}$ heisse Luft und bläst sie über ein Rohr mit einem Durchmesser von $0.2 \mathrm{~m}$ senkrecht von unten in den Kanal ein. Die Wände und die Decke des modular aufgebauten und neigbaren Kanals sind isoliert. Die Bodenplatten sind aus Glas gefertigt und erlauben den Einsatz eines Laser Doppler Messverfahrens (LDA) zur berührungslosen Bestimmung der Strömungsgeschwindigkeiten. Die Temperaturmessungen erfolgen mit Thermoelementen. Nebst den Messungen stromab des Heissluftstrahls, die der Validierung dienen, werden auch die zur numerischen Simulation notwendigen Einlassrandbedingungen gemessen. Für die LDA Messungen werden sowohl die Längsströmung als auch der Heissluftstrahl mit Salzkristallen beschickt, welche mit einem gewöhnlichen Ultraschallzerstäuber in einer Salzwasserlösung durch Zerstäubungsund Verdampfungsprozesse erzeugt werden. In einem Vorversuch wurden die Kristallgrössen für verschiedene Salzkonzentrationen der Lösung gemessen. Es zeigt sich, dass die Kristallgrösse über die Salzkonzentration gezielt beeinflusst und auf das jeweilige Experiment abgestimmt werden kann.

Bei den CFD Simulationen werden zwei unterschiedliche Gitter verwendet: Das eine löst die Wandgrenzschichten nicht auf, was zur Konvergenz der stationären Simulationen führt. Das zweite hingegen löst die Wandgrenzschichten auf. Auf diesem Gitter konvergieren die stationären Simulationen nicht mehr, so dass transiente Simulationen durchgeführt werden müssen. Die stationären Simulationen auf dem Gitter ohne aufgelösten Grenzschichten liefern keine befriedigenden Ergebnisse. Sie hängen zudem stark von der Wahl des Turbulenzmodells ab. Die transienten Wirbelstrukturen in der Nähe des Heissluftstrahls werden unterdrückt, was zu einer geringeren Einmischung kalter Luft in den Heissluftstrahl und somit zu höheren Deckentem- 
peraturen, im Vergleich zu den transienten Rechnungen, führt. In den transienten Simulationen auf dem Gitter mit aufgelösten Grenzschichten werden diese Strukturen wiedergegeben. Bei der transienten SST Simulation (Shear-Stress Transport) werden nur dominante Strukturen aufgelöst, was zu einer geringen Verbesserung der Lösung im Vergleich zur stationären SST Rechnung führt. Die DES Simulation (Detached Eddy Simulation) liefert detailliertere Strukturen, arbeitet aber auf dem gewählten Gitter in vielen Bereichen im SST Modus. Auf demselben Gitter vermag das SAS Modell (Scale-Adaptive Simulation) beinahe überall im Wirbel auflösenden Modus zu arbeiten und liefert vor allem im Nachlauf sehr gute Ergebnisse. Es ist das einzige Modell, das auf dem gewählten Gitter sowohl die Rückströmung an der Decke in der Nähe des Heissluftstrahls als auch die Wirbelablösefrequenz im Nachlauf des Strahls adäquat wiedergeben kann. 